EESTI NSV TEADUSTE AKADEEMIA TOIMETISED 1954. III kd., nr. 2

ИЗВЕСТИЯ АКАДЕМИИ НАУК ЭСТОНСКОИ ССР 1954. ТоМ III, № 2

\title{
EESTI MAAD MUISTSE VENE RIIGI KOOSSEISUS *
}

\author{
A. VASSAR, \\ ajalooteaduste kandidaat
}

Eesti rahvale, nagu teistelegi NSV Liidu rahvastele, on Ukraina Venemaaga taasühinemine väga lähedane ja suure tähtsusega ajalooline sündmus. Sügavad ajaloolised juured ühendavad eesti rahva saatust ukraina rahva saatusega ning nende ühise ustava sõbra ja kaitsja - suure vene rahva - saatusega.

Muistse Vene riigi, mille keskuseks oli Kiiev, asutas muinasvene rahvas. Sellest ühtsest tüvest põlvnevad vene, ukraina ja valgevene rahvad, kes kunagi ei kaotanud teadmist oma päritolu ja saatuse ühtsusest. Muistses Vene riigis, milles peamiseks ja juhtivaks jõuks oli muinasvene rahvas, elas rida mitteslaavi hõime ja rahvaid, keda mainitakse vanimates vene kroonikates. Nende hulgas on korduvalt juttu ka tšuudidest ehk eestlastest. Kõigi nende rahvaste elus oli Muistse Vene riigi periood murrangulise tähtsusega etapiks, mis ühendas nende rahvaste saatused.

Vene maade ühinemisega Kiievi ümber, eriti aga Novgorodi liitumisega IX sajandi teisel poolel, algas Muistse Vene riigi kindlustumine ja kasv. Valitsev feodaalide klass vajas tugevat suurvürsti võimu, nagu see oli väljı kujunenud kaugemale arenenud Lõuna-Venes, kus Kiievi vürstid omasid suuri maavaldusi. Kohalike feodaalide toetus võimaldas Kiievi vürstide võimu kiire leviku määratu suurel maa-alal. Muistne Vene riik soodustas feodaliseeruva ülikkonna ja feodaalide klassi positsioonide kindlustumist.

Samal ajal liitis Muistne Vene riik rea rahvaste killustatud jõude IdaEuroopas ja purustas Bütsantsi valitsejate, kasaaride ja teiste vaenlaste katsed siinseid rahvaid alistada. Vaenlased said tunda vene vastulöökide jôudu. Uhendades oma valdustes Baltimaade ja põhjapoolsete rahvaste maad, ajas Muistne Vene riik nurja skandinaavlaste rüüsteretked ja vallutuslikud kallaletungid. Samal ajal kui viikingid panid Lääne-Euroopas inimesed värisema oma rüüsteretkedega, muudeti nad Venemaal palgalisteks, kes teenisid vene vürstide vägedes.

Muistse Vene riigi tekkimisega kujunesid Ida-Euroopa rahvastel soodsad tingimused tootlike jõudude, ühiskondlike suhete ja kultuuri arenguks. Muistne Vene riik omas väljapaistvat kohta Euroopa ja Aasia maade hulgas, milledega tal olid laialdased ja tihedad sidemed.

Eesti hõime sidusid slaavi hõimudega põlised majanduslikud ja kultuuri-

* Ettekanne Eesti NSV Teaduste Akadeemia teaduslikul sessioonil Ukraina Venemaaga taasühinemise 300 . aastapäeva tähistamiseks, 13. mail 1954. a. 
lised sidemed. Arheoloogilised ja keeleteaduslikud andmed räägivad eesti ja teiste läänemere hõimude suhtlemisest slaavi hõimudega juba I aastatuhandel enne meie ajaarvamist. Sellest annavad tunnistust idaslaavlastelt tulnud kõige vanemad keelelised laenud, vanad kultuurisõnad nagu näiteks hirs (palk või latt), ike (härjarakendi osa), und, koonal jt.'

Väärib märkimist, et silmapaistvama ja juhtiva slaavi rahva - ve ne rahva nimetus eesti keeles pärineb juba kuni ligikaudu kaks tuhat aastat tagasi toimunud suhtlemisest läänemere hõimude ja veneedide-nimelise slaavi hõimu vahel ${ }^{2}$.

Eriti selge pilt avaneb meile eesti ja idaslaavi hõimude tihedatest ja sõbralikest suhetest alates I aastatuhande esimesest poolest meie ajaarvamise järgi. Tollal oli eesti-liivi-vadja hõimude juures levinud komme oma surnuid matta maapealsetesse kivikalmetesse, idaslaavlastel aga liivast kuhjatud kääbastesse. Need olid veel sugukondlikud matusepaigad ning olid seotud omapärase rituaaliga, mis võimaldab neid kasutanud kogukondi etniliselt kindlaks teha.

Eesti hõimud puutusid sajanditel enne Muistse Vene riigi tekkimist vahetult kokku eelkõige krivitšitega, suure idaslaavi hõimuga, kes oli levinud Dnjepri, Zapadnaja Dvinaa ja Volga jõgede ülemjooksul ning Veliikaja jõe ja Pihkva järve piirkonnas. Krivitšitele olid iseloomulikud pikad kääpad, mida dateeritakse III-IX sajandile. Nendest ida ja põhja pool, Lovati, Ilmeni ja Volhovi piirkonnas asunesid samal ajal novgorodi sloveenid, kes matsid oma surnud kõrgetesse liivakääbastesse, nn. sopkadesse ${ }^{3}$. Krivitšite pikad kääpad on levinud ka Kagu-Eestis, kus neid esineb Räpina, Vastseliina, Võru ja Põlva rajoonides, Antsla ja Tartu rajooni idaosas ning väiksemal määral veel Kallaste rajoonis ja Mustvee rajooni lõunaosas. Pikkade kääbaste levikuala seostub vahetult kivikalmete levikualaga, kohati leiduvad aga mõlemad kalmetüübid samas piirkonnas ja üksikuil juhtudel isegi samal kalmeväljal (näiteks Vastseliina rajoonis Loosi Kivikülas). S. A. Tarakanova on näidanud, et siin ei saa küsimusse tulla krivitšite matmisvormi ülevõtmine eestlaste poolt, vaid tegemist on eestlaste ja krivitšite elamisega vahetus naabruses, kohati aga koguni eesti-slaavi segaasustusega ${ }^{4}$.

Selline asustus võis tekkida ja sajandeid püsida ainult eesti ja idaslaavi hõimude tiheda ja sõbraliku suhtlemise tingimustes. Niisugusest suhtlemisest jutustavadki arheoloogilised leiud ja keeleteaduslikud andmed III-VIII sajandist. Eestlased õppisid tollal slaavlastelt tundma mitmesuguseid uusi tööriistu ja tootmiskogemusi, ehteasju jne. Nii on slaavlastelt pärit emaili valmistamise oskus, varrelappidega kitsaskirves ning mitmed uued sõlgede, ripatsite ja kaelavõrude vormid. Slaavlaste kaudu sattusid Eestisse isegi mõningad kaugelt pärit importesemed, nagu Varnjast ja Kriimanist leitud bütsantsi hõbenõud, Kesk-Dnepri alal elavatele antidele tüüpiline sõrmiksõlg Jägala Jõesuu linnuselt, ida-rooma kuldmünt Väike-Vilsandi saarelt jm. Kuid mõningad eestlastele tüüpilised esemed levisid aga ka krivitšite hulka, nagu näiteks ovaalsed tuluskivid, mõni käevõru ja sõlg. Seega olid suhted vastastikused ja viljakad. Oldiselt oli aga slaavi kultuuri ja keele mõju eesti hõimudele tugevam, sest oma põhja-

1 P. A ris te, Eesti ja vene rahva sõbralikud suhted keeleteaduse valguses. „Rahva Hääl" nr. 252, 25. okt. 1951. a.

2 П. Н. Т р етья ко в, Восточнославянские племена. Издание второе, М. 1953, стр. 105; P. A r iste, Slaavlaste ja läänemerelaste vanimaist keelelisist kokkupuuteist. „Looming”" 1952, nr. 6, lk. 700.

3 П. Н. Т ре ть яков, tsiteeritud teos, lk. 229.

4 Vt. ENSV TA Toimetised 1952, I k., nr. 1, lk. 124. 
poolsete naabritega võrreldes sammusid idaslaavlased majanduslikus, kultuurilises ja poliitilises arengus ees.

Eriti V-VIII sajandil toimus varanduslik eristumine, ülikkonna eraldumine hulkadest nii eestlaste kui ka krivitšite juures. On märkimisväärne, et suhtlemine ei toimunud sugugi üksnes ülikate vahel - mis kajastub eriti slaavi hõbeehete levikus Eestis -, vaid otseselt ka rahvahulkade vahel. Viimast peegeldavad näiteks ühised jooned keraamikas, samuti slaavi laenud eesti keeles.

Ilmselt sellest perioodist on pärit Peipsi järve venekeelne nimetus Чудское озеро. Kui krivitšid I aastatuhande keskpaiku levisid kummalegi poole Peipsi järve lõunaosa, siis kuulus see eesti-vadja hõimude piiridesse. Neid hõime nimetasid slaavlased nähtavasti tšuudideks. Hiljem, kui hakkas kujunema eesti ja vadja rahvas, märkisid venelased viimast eri nimetusega (вожане, водь XI-XII sajandi vene kroonikates), tšuudi nimega tähistati aga eestlasi ${ }^{5}$. Kuigi hiljem tšuudi nime kasutamine laienes, mõistis näiteks Ivan Groznõi Jaroslav Targa aegse Tšuudimaa nime all just Eesti ala (ehk Liivimaad, missugune nimetus tol ajal oli üldisemalt tuntud ja tähistas laiemat territooriumi, hõlmates ka Eestimaa) ${ }^{6}$.

Krivitšite asustus Kagu-Eestis, paigutine eesti-slaavi segaasustuse kujunemine ning arheoloogilistes leidudes ja keeles avalduvad tihedad suhted eesti ja idaslaavi hõimude vahel enne Muistse Vene riigi tekkimist on väga olulised IX-XII sajandil valitsenud olukorra mõistmiseks. Eestlaste tihedad sidemed Muistse Vene riigiga olid juba sajandeid kestnud majandusliku ja kultuurilise läbikäimise otseseks jätkuks ja edasiarenguks. Eestlaste allumine Kilevi vürstidele oli eelneva arengu, klassiühiskonna tekkimise ja ühise kaitsevajaduse seaduspäraseks tulemuseks.

Eesti territooriumi rahvastik elas IX-XII sajandil läbi feodaliseerumise protsessi. Tootlike jõudude seisundis toimusid tollal olulised muutused, millele vastavalt arenesidki feodaalsuhted, need aga omakorda määrasid tootlike jõudude tunduva tõusu. Uldiselt levis nüüd raudotsaga ader, mis võimaldas künnipõllunduse arenemist ja üksikperele kuuluva talumajapidamise tekkimist. Kui alepõllunduse tingimustes teatud madalad paepealsed või liivased maad Eesti alal ei olnud maaharimiseks küllalt kõlblikud, siis adra tarvituseletulekuga ja maa väetamisega muutusid needki piirkonnad põllunduslikult kasutatavateks. See soodustas asustuse tihenemist ja põllumajandusliku tootmise kasvu. Olgu märgitud, et raudotstega atra õppisid eestlased tõenäoliselt tundma venelastelt, millega seoses eesti keeles kodunes sõna sahk. Põllundusliku tootmise kasvuga levis eestlaste keskel ka uus venepärane sirp, mis võimaldas tõsta töötootlikkust viljalõikamisel. Tali- ja suvivilja kasvatamisega põlispõldudel hakkas levima kolmeväljasüsteem. Nii kujunesid sel perioodil pôllutöö alal välja tööriistad ja tootmiskogemused, mis püsisid kogu feodalismi ajastu.

Käsitöö alal toimus täienemine, käsitöö hakkas eralduma põllundusest. Rida venepoolseid laene eesti keeles kudumise ja ehituse alal (näit. värten, piird, pasmas, aken jt.) tunnistab vene käsitööliste viljakast edasiviivast mõjust eestlastele. Savinõude valmistamisel tuli Eestis venelaste eeskujul tarvitusele pottsepaketas hiljemalt XI sajandil, linnalistes keskustes aga võib-olla veelgi varem.

Uhiskondliku tööjaotuse ning käsitöö ja kaubanduse arenemise tulemuseks oli linnailmeliste keskuste tekkimine Eestis X-XII sajandil (Tallinn,

5 Esmakordselt mainitakse vadjalasi 1069. aastal. Vt. Новгородская первая летопись старшего и младшего изводов. М.-Л. 1950, стр. 17; vadjalasi ja tšuude (eestlasi) eristatakse kroonikas selgesti, vt. samas $1 \mathrm{k} .78$.

6 Послания Ивана Грозного. Под редакцией В. П. Адриановой-Перетц, М.-Л., 1951, стр. 202: «....нже тое Чюдскую землю плени, еже есть Лифлянты,.» 
Tartu, Otepää, Varbola jt.). Nende tugevnemisele aitas kaasa tihe suhtlemine Vene linnadega, eriti Novgorodi ja Pskoviga.

Arheoloogilised kaevamised Tallinna Toompeal ja vanalinnas raekojaplatsil näitasid püsiva asula tekkimist algul linnuses, kuid seejärel ka all-linna alale juba umbes IX $-X$ sajandil. Tihedatest eesti-vene suhetest siin annab tunnistust näiteks asjaolu, et Tallinna kaevamistel leitud kedrakeraamika vastab vana-vene keraamikale ${ }^{7}$. Keraamilised esemed on aga teatavasti massitoodang, mida valmistatakse tavaliselt kohapeal ja mis lihtrahva elu-olus etendab olulist osa. Nagu vene kroonikast teada, ehitati Tartu (Jurjev) Kiievi vürsti Jaroslavi poolt 1030. aastal. Eesti rahvaluules on rohkesti andmeid venelaste abi kohta eesti linnade ehitamises (laudade toomine Pihkvast või Peipsi tagant). Linnatänava nimetus uulits on vana-vene laensõna eesti keeles.

Nagu näitavad ülalesitatudki arheoloogilised ja keeleteaduslikud andmed, etendas suhtlemine venelastega tähtsat osa tootlike jõudude arenemises Eestis IX-XII sajandil.

Sugukonna-hõimu kord oli eestlastel selleks ajaks lagunenud ja aset andnud territoriaalsetele kogukondadele. Põllumaad olid juba läinud üksikute talupoegade valdusesse, mille alusel toimus maksustamine. Samal ajal süvenes varanduslik ebavorrdsus. Mündi- ja aardeleiud, panustelt rikkad ja vaesed matused, hõbeehete, ilustatud odaotsade ja mõõkade levik, uute, ülikatele kuuluvate linnuste tekkimine endiste kogukondlike linnuste asemele - kõik see tõendab rahvahulkadest eraldunud ülikate, nn. paremate olemasolu. Nende jõukuse ja võimu aluseks oli tekkiv suurmaavaldus, orjade ja sõltuvusse viidud kogukondlaste-talupoegade ekspluateerimine.

Talupoegade ekspluateerimise vormiks oli neil sajandeil andam (дань). mille kohta vene kroonikates ja skandinaavia saagades on andmeid alates IX-X sajandist. Andami kogumist ja kohtumỗistmist teostasid kohalikud ülikad, milleks maa oli jagatud vakusteks (Ipatjevi kroonikas mainitud pogostid) ${ }^{8}$, või ringkondadeks (vene губ́a). Viimasest tuleneb ka sõna kubjas $^{9}$, mis hiliem tähendas feodaalmõisniku abilist talupoegade hulgast. Sõltuvate talupoegade ja orjade ekspluateerimise vormina rakendati rikaste maavaldajate poolt ilmselt ka tegu. Rikaste maavaldajate käes oli kohtuvõim, samuti esinesid nad peamise sõjalise jõuna, olles paremini relvastatud. Kihelkondades ja „maades” oli võim päritavalt kõige rikkamate maavaldajate ehk vanemate käes. Kõik see aitas tugevdada feodaalide majanduslikku võimu ning maha suruda sõltuvate talupoegade ja orjade rahulolematuse avaldusi.

Feodaliseerumise protsessis rajati alused eesti rahva kujunemiseks. Vanima vene kroonika „Jutustus möödunud aegadest” alguses antud ülevaates mainitakse teiste slaavi ja mitteslaavi hõimude hulgas tšuude, rõhutades, et igaüks neist hõimudest räägib oma keelt ${ }^{10}$. Seega tunti Venes tšuude (eestlasi) tollal kui oma keelt rääkivat rahvast. Muistse Vene riigi koosseisus sai eesti rahvas võimaluse sel määral välja kujuneda, et ta hiljem suutis vastu panna saksa orjastajate sajandeid kestnud rõhumisele ja hävitamisele ning edasi areneda, kaitstes oma põlist territooriumi ning arendades oma keelt ja kultuuri.

Seoses tootlike jõudude kasvuga ja feodaalsuhete kujunemisega tihenesid eestlaste suhted kõrgel ühiskondlik-majanduslikul ja kultuurilisel tasemel

7 S. A. Taraka nova, Arheoloogilised kaevamised Tallinnas. ENSV TA Toimetised 1952 , I k., nr. 4, 1 k. 57 ; H. M o o r a, Tallinna tekkimisest ja vanusest. ENSV TA Toimetised 1953, II k., nr. 2, lk. 173.

8 Повесть временных лет, часть первая, М.-Л., 1950, стр. 201.

9 Dots. A. Kaselt saadud andmeil.

10 Повесть временных лет, стр. 13. 
seisva muinasvene rahvaga ja tema poolt asutatud Muistse Vene riigiga. Muistse Vene riigi perioodil laienes ja mitmekesistus eestlaste ja venelaste läbikäimine võrreldes eelnevate sajanditega. Muististe levik, arheoloogilised leiud ning keeleteaduslikud ja muud andmed kinnitavad ühtviisi, et see läbikäimine oli sõbralik ja vastas mõlema rahva elulistele huvidele.

Endine krivitšite asustus Kagu-Eestis nähtavasti sulas pikkamööda eestlaste hulka, mida näitab pikkade kääbaste kadumine ja eestipäraste leidude levik X-XII sajandil. Mõningal määral leidus siin siiski venelasi ka neil sajandeil, nagu näitavad üksikud slaavipärased leiud (luunulad, teatud sõrmusetüübid jne.). Samal ajal ilmneb aga selles piirkonnas tugev slaavi mõju. Ida-Eestis on sellal eestlastele iseloomulik maa-alune kalmistu, kuid umbes samades rajoonides, kus varem leidusid pikad kääpad, on nüüd levinud slaavipärased ümmargustest kääbastest koosnevad kalmistud, olles tunduvalt suuremad ja arvukamad, mis on tingitud asustuse kasvust. Seejuures pole IX-XII sajandi kääpad enam sugukondlikud matusepaigad, nagu pikad kääpad, vaid individuaalkalmed, mis on seletatav ühiskondlikes suhetes toimunud muutustega. Slaavipärase matmiskombe levik idaeestlaste juures näitab elanike laialdaste kihtide vahel toimunud suhtlemise pikaajalisust ja selle suhtlemise sõbralikku iseloomu, mis viis perekondlike sidemete tekkimisele.

Kääbaskalmed ilmusid XI-XII sajandil ka Peipsi järvest pōhja pool olevasse piirkonda, kus metsarikkad alad said nüüd püsiva asustuse (Mustvee rajoon ning Jõhvi rajooni lõuna- ja keskosad). V. V. Sedov on oma uurimuses Suur-Novgorodi loodemaade rahvastiku etnilise koostise kohta tõestanud, et kuni XI sajandini toimus slaavlaste asumine vadjalaste keskele Peipsi järve kirdekaldal. XI sajandil tekkis slaavi ja osalt slaavivadja segaasustus Narva jõe ülemjooksul ja Alutaguses (Jõuga) ${ }^{11}$. Slaavlaste kolonisatsioon toimus ilmselt rahulikul teel, siia varem asunud vadjalaste või lääne pool Narva jõge olevate eestlaste hulka. Uued kääbaskalmistud ilmuvadki siin tavaliselt seni asustamata piirkondadesse, s. t. varem mõnele sugukonnale kuulunud metsamaadele.

Seega toimus XI-XII sajandil Kirde-Eestis asunevate eestlaste territoriaalne lähenemine slaavlastele ja osalt segaasustuse kujunemine. Kääbastesse matmise komme levis mõnevõrra ka põhja poole vana asustusega paelava alale Soome lahe ääres. Järelikult laienesid eestlaste kokkupuuted venelastega tunduvalt, mis ei saanud jääda kajastumata majanduses ja kultuuris. IX -X sajandini oli slaavlastega läbikäimise ja slaavi mõjude sissetungi väravaks peamiselt Kagu-Eesti, nüüd aga kujunes uueks väravaks Narva jōe piirkond. See on seotud slaavlaste kolonisatsiooni nihkumisega pōhja poole ja Novgorodi kui Põhja-Venemaa tähtsaima käsitöö-, kaubanduse-, administratiiv- ja kultuurikeskuse esiletõusuga.

Venelastelt tundma õpitud tööriistadest tõime mõningaid näiteid seoses tootlike jōudude olukorra käsitlemisega. Slaavipärase keraamika laialdane levik, eriti Ida- ja Kesk-Eestis kuni Tallinnani, tunnistab laiade hulkade vahelisest elavast suhtlemisest. Slaavlastele iseloomulikud mitmesugused helmed, sõrmused, tinanaastukesed, ristikesed jne. leidsid kasutamist. ka eestlaste keskel, kusjuures nende esinemise rohkus kasvab ida suunas. Mõned slaavlaste ehted saavutasid eestlaste juures eriti laialdase leviku, nagu näiteks kolmest traadist punutud käevõrud (XII-XIII saj.). Läbikäimine venelastega avaldas suurt mõju eesti ülikatele. Seda tõendavad mündi- ja aardeleiud, hōbeehted jne. Arusaadavail põhjusil avaldub linna-

11 В. В. С едов, Этнический состав населения северо-западных земель Великого Новгорода (IX-XIV вв.), Советская археология, XVIII, M., 1953, стр. 212. 
listest keskustest, näiteks Tartust, Otepäält ja Tallinnast saadud arheoloogilistes leidudes venepoolne mõju väga tugevasti.

Arvukad mündi- ja aardeleiud, mis Eesti alal on koondunud suuremate keskuste ja sadamakohtade ning tähtsaimate teede kohale, näitavad Vene kaubanduse väga suurt tähtsust eesti majandusele IX-XII sajandil, peegeldades ühtlasi ühiskondliku arengu taset. Mõningad kirjalikud andmed kinnitavad mitte ainult, et venelased käisid Eestis, vaid et eestlased külastasid ka Novgorodi. 1176. aastal mainitakse Novgorodi kroonikas esmakordselt Volhovi läänepoolsel kaldal asuvat Tšudinetsi uulitsat, mis löppes samanimeliste väravatega. Nimetus on tõenäoliselt tulnud sellel uulitsal elavatest kaupmeestest, kes kauplesid Tšuudimaaga (Eestiga) või ka eestlastest, kes elasid Novgorodis ${ }^{12}$.

Norra kuninga Olaf Tryggvasoni saagas on säilinud tähelepanuväärne jutustus X sajandi lõpust, kuidas novgorodlased tormiliselt nõudsid, et hukataks varjaag Olav, kes isikliku kättemaksu ajel tappis turul kirvega Novgorodi tulnud eestlase. Novgorodis kehtis nimelt kindel rahu, ja seal oli seadusega keelatud tappa kedagi, kes kohtu poolt polnud surma mõistetud. Ainult vürsti ja ta naise vaheleastumine ning suure relvastatud družiina kokkukutsumine päästis mõrvari rahva viha eest ${ }^{13}$.

Nagu on kindlaks teinud I. P. Saskolski, läks IX -XIII sajandil tähtsaim kaubatee Novgorodist läände Neeva suudmest piki Soome lahe eestipoolset rannikut kuni Tallinnani, mida vene bõliinades nimetatakse „,kuulsaks Ledenetsi linnaks". Osalt purjetati siit edasi piki Eesti rannikut, osalt aga risti üle lahe Soome rannikule ja sealt edasi Rootsi ning kaugemale löunasse ${ }^{14}$. Seetõttu oli muistne Tallinn tähtsaks keskuseks mitte ainult eesti-vene, vaid ka Vene ja Lääne-Euroopa vahelises kaubanduses. Vene kaupmeeste osa siin näitab iseloomulik üksikasi, et tolleaegne Kalevilinn (Tallinn) sai kuni Vahemeremaadeni tuntuks just venepärase nime - Kolõvan - all (geograaf Idrisi kirjeldus 1154. aastast).

Kaubandussuhete tähtsust majanduslikus ja kultuurilises läbikäimises peegeldab ka vene kaalu- ja rahasüsteemi levik Eestis ning vastav eesti keeles kodunenud vene päritoluga sõnavara: turg, määr, päsmer, puud (pund) ${ }^{15}$.

On seaduspärane, et selline tihe läbikäimine avaldub ka mõningate eestipoolsete elementide esinemises venelaste keskel. Näiteks on Izborski linnamäelt leitud eestlastele tüüpiline ristpeanõel, Zalahtovjes aga mõningaid eestipäraseid nõelu ja teisi ehteid jm.

Järjest tihenevad majanduslikud ja kultuurilised sidemed, feodaalsuhete kujunemine ning kaitsevajadus välisvaenlaste vastu oli aluseks eestlaste poliitilisele ühendusele Muistse Vene riigiga. Eesti feodaliseeruv ülikkond oli huvitatud vene vürstidele allumisest, sest see kindlustas ülikatele rahvahulkade ekspluateerimise ja pakkus neile võimalusi rikastumiseks sõjakäikudest osavõtmise ja feodaalvalduste saamise teel. Ohtlikuks välisvaenlaseks olid neil sajandeil skandinaavlased. Skandinaavia saagades on andmeid skandinaavlaste arvukatest veristest rüüsteretkedest Eesti alale juba VII sajandist alates. Varjaagide kallaletungid võtsid eriti suure ulatuse IX sajandil. Muistne Vene riik oli tollal ainsaks jõuks, mis suutis varjaagide röövellikule tegevusele otsustavalt piiri panna. Muinasvene

12 М. Н. Т ихоми ров, Древнерусские города, М., 1946, стр. 43.

13 Antiquités russes I, Copenhague, 1850, 1k. 277.

14 И. П. Ш а скольски й, Маршрут торгового пути из Невы в Балтийское море в IX-XII вв., Географический сборник III, 1954, стр. 146-159.

15 А. А. Ильин, Топография кладов древних русских монет X-XI вв. Л. 1924 , lk. 13 on märgitud Jaroslav Targa hōbemündi leid Saaremaalt, B. A. Rōbakov asetab nähtavasti sama leiu aga Tartu juurde, vt. Советская археологля № 6, M.-Л. 1940, стр. 256 
rahva abi võimaldas eestlastel IX-XII sajandil tagasi lüüa kõik skandinaavlaste kallaletungid.

Vene kroonikates on säilinud pärimuslikke teateid varjaagide vägivallast tšuudide, novgorodi slaavlaste, krivitšite jt. kallal IX sajandi keskpaiku. Novgorodi kroonikas jutustatakse, et novgorodlased ja krivitšid koos tšuudidega kihutasid varjaagid minema, ,hakkasid ennast ise valitsema ja linnu asutama" ${ }^{16}$. Edasi jutustatakse sündmustest paarkümmend aastat hiljem, kuidas Novgorodi vürst Oleg kogus suure sôjaväe novgorodi slaavlastest, krivitšitest, tšuudidest ja teistest ning teostas ulatusliku sõjakäigu lõunasse, mille tulemusena toimus Kiievi ja Novgorodi ühendamine üheks riigiks. Kiiev muutus ,vene linnade emaks”, s. t. Muistse Vene riigi keskuseks.

Põhjapoolsete slaavi ja mițteslaavi hõimude tihe side ja ühine väljaastumine varjaagide vastu IX sajandil selgub kroonika pärimuslikest teadetest ilmse tõsiasjana. Missugune see poliitiline ühendus tegelikult oli, pole andmete puudulikkuse tõttu võimalik kindlaks teha. Tšuudide ühendus mitte ainult krivitšitega, vaid ka Novgorodiga on nendes pärimustes aga selgelt fikseeritud ${ }^{17}$.

IX sajandi lõpul ja X sajandi algul, vürst Olegi valitsemise ajal tõi Muistse Vene riigi kiire kasv olukorda muutuse. Ka põhjapoolsed maad, sealhulgas Novgorod, maksid nüüd andamit Kiievi vürstile.

Milles väljendus Kiievi vürstide võim neile alluvates maades? Esiteks elanikkonna maksustamises andamiga ja teiseks tema kaasatõmbamises Kiievi vürstide sõjakäikudest osavõtmiseks. Vene allikad ei maini tšuude andamimaksjate hulgas X sajandil, kui mitte arvestada ajaliselt lähemalt määramata teadet vene kroonikas „Jutustus möödunud aegadest”, mille vanim säilinud tekst on koostatud XII sajandi algul. Seal märgitakse Venele andamit maksvate mitteslaavi rahvaste hulgas tšuude. Olaf Tryggvasoni saagas on siiski teateid, et X sajandi 70 . aastatel käidi Novgorodist Eestis vene vürstile andamit kogumas ${ }^{18}$. Selle kohta aga, millal ja kuidas tekkis andami maksmine vene vürstile, puuduvad andmed.

Seevastu teatab vene kroonika korduvalt tšuudide osavõtust LõunaVene vürstide kaugetest sõjakäikudest X sajandil (907. aastal Bütsantsi vastu, 980. aastal Polotski vastu, millise sõjakäiguga see liideti KiieviVenemaa koosseisu). X sajandi löpul värbas Vladimir Svjatoslavitš vabatahtlikke kohalike ülikate, sealhulgas ka tšuudi ülikate hulgast riigi lõunapiiri kaitsmiseks stepi-rändhordide rüüstekäikude vastu. Olikad siirdusid Iõunasse uutesse ehitatud linnadesse koos oma družiinadega ${ }^{19}$. Andmed eestlaste aktiivse osavôtu kohta Vene vägede koosseisus nii riigi territooriumi laiendamisest kui ka võitlusest välisvaenlaste vastu annavad tunnistust nende tihedast poliitilisest ühendusest Muistse Vene riigiga.

Kõigist neist andmeist võib järeldada, et tšuudid allusid $\mathrm{X}$ sajandil Kiievi vürstidele. Võimatu on kindlaks teha allunud territooriumi, kuid eelkõige tuleb küsimusse muidugi Kagu-Eesti, kus slaavi mõjud olid kõige tugevamad.

XI sajandil, kui suurenes Kiievi vürstide huvi Eesti vastu, tugevnesid sidemed Kiieviga veelgi rohkem. Uhelt poolt oli see huvi tingitud püüdest laiendada maavaldusi ja maksualuseid piirkondi ning kindlustada feodaalide võimu, teiselt poolt vajadusest julgestada läände viivaid kaubateid

16 Новгородская первая летопись, стр. 106.

17 Повесть временных лет, стр. 20. Selle teatega on vastuolus A. N. Nassonovi väide, nagu ei mainitaks tšuude kunagi Novgorodi väe koosseisus (A. H. Н а с о н о в, *Русская земля» и образование территории древнерусского государства, М. 1951, стр. 71).

18 Antiquités russes I, lk. 276, vrd. lk. 396-397, 417.

19 A. H. H а сонов, tsiteeritud teos, lk. 67. 
ning vältida Eesti ala sattumist skandinaavia röövvallutajate võimu alla. X-XI sajandil võime märkida kaubanduslike sidemete tunduvat laienemist Vene riigi ja Lääne-Euroopa maade vahel üle Balti mere, mis oli ühiskondliku tööjaotuse edasise arengu tulemuseks. Samal ajal, X sajandi lõpul ja XI sajandil sagenesid skandinaavlaste röövretked Balti maadele, millest jutustavad skandinaavia saagad ja ruunikivid.

Jaroslav teostas 1030. aastal retke Eestisse ja asutas Jurjevi (Tartu) kindluse, ilmselt juba varasema eestlaste linnuse kohale. On arvatud, et Jaroslav lõi siia oma pärusvalduse. Igal juhul märgib see sündmus Kiievi vürsti võimu tugevnemist Kagu-Eestis. XI sajandi keskpaiku laiendas Kiievi vürst Izjaslav Jaroslavitš oma võimu Eesti alal (retk tõenäoliselt Keava linnuse alla 1055. aasta paiku ja sossolite maksustamine 1060 . aastal).

Vene vürstid ei seganud end neile alluval eestlaste maal siseasjadesse, ei loonud siin tavaliselt oma suurmaavaldust, ei teostanud sõjalist okupatsiooni ega vägivaldset ristiusustamist. Nad olid huvitatud eelkõige andami saamisest ja kaubateede kindlustamisest. Allumine Kiievi vürstidele aitas kindlustada kohalike eesti ülikate majanduslikku ja poliitilist võimu ning andis neile tõusuvõimalusi vürstide teenistuses. Juba X sajandist on arvatud võivat ära tunda eesti družinnikute nimesid Venemaa ,ühiste saadikute" nimestikus lepingu sõlmimisel Bütsantsiga 944. aastal. Eesti ülikate seast olid pärit mõned Kiievi vürstide vanemad družinnikud XI sajandil, kes võtsid aktiivselt osa riigi poliitilisest elust (Vene kroonikas korduvalt mainitud Mikula Tšudin ja ta vend Tukõ) ${ }^{20}$. Hiljem omas väljapaistvat positsiooni Vladimir Monomahhi juures Ivanko Tšudinovitš.

Feodaalsuhete arenemise tulemusena hakkasid XI-XII sajandil pikkamisi eesti ühiskonda tungima ristiusu elemendid (ristiusu môju matustes, ristikeste leiud, keelelised andmed). Kõige suuremat mõju avaldas Eestis vene kirik, mis tollal etendas progressiivset osa, aidates kindlustada feodaalset baasi ${ }^{21}$.

Feodaalse tootmisviisi arenemine, üksikute kohalike keskuste tugevnemine ja klassivõitlus viisid maa poliitilisele killustumisele. XII sajandi algul algab meie maa ajaloos uus periood, feodaalse killustumuse periood. See oli seaduspärane, progressiivne etapp ühiskonna arengus, kuid ta tõi kaasa ka negatiivseid nähtusi, nimelt alatisi feodaaltülisid ja sõdu. Feodaalsuhete arenemine Baltimaade rahvaste juures lōi sel perioodil eeldused iseseisvate riikide kujunemiseks. Leedus kujuneski iseseisev feodaalriik, Eesti ja Läti alal katkestas selle protsessi aga saksa-taani röövvallutajate sissetung XIII sajandil.

XI sajandil algas Novgorodi eraldumine Kiievi-Venemaast, mis lõppes 1136. aastal bojaaride vabariigi kehtestamisega. Novgorodlased allutasid Pskovi endile nähtavasti juba XI sajandi keskpaiku ${ }^{22}$. Novgorod võttis enda kätte ka andami kogumise Eestis, mis XI sajandil oli kuulunud Kiievi vürstidele. Novgorod oli kujunenud suureks käsitööstuslikuks ja kaubanduslikuks ning feodaalide sõjalis-administratiivseks keskuseks. Kui IX-XI sajandi Venemaal Balti mere kaubanduse peamine osa kuulus Kiievile, siis XI-XII sajandist alates muutus Novgorod Balti mere kaudu Lääne-Euroopaga peetava kaubavahetuse suurimaks keskuseks ${ }^{23}$, kust valitseti niihästi peamist teed üle Soome lahe kui ka teid läbi Eesti. Nov-

20 Очерки истории СССР. Период феодализма, IX-XV вв. в двух частях, Часть I, M., 1953 , стр. 689 .

${ }_{21}$ Vt. pikemalt J. S a skolski, Vene rahva ajaloolised sidemed Baltimaade rahvastega, Tallinn, 1946, lk. 20-21.

22 A. H. $\mathrm{H} \mathrm{а} \mathrm{со} \mathrm{н} \mathrm{ов,} \mathrm{tsiteeritud} \mathrm{teos,} \mathrm{Ik.} 81$.

23 История культуры древней Руси. Домонгольский пернод, І, М.-Л., 1948, стр. 346. 
gorodi majanduslik ja kultuuriline mõju Eestis kasvas XI-XII sajandil kiiresti. Eestlased olid eluliselt huvitatud sidemetest Novgorodiga. Kõik see tingis seda, et võitlus Eesti ala pärast läks XII sajandi algusest peale täiesti Novgorodi kätte, kellega selles küsimuses käis käsikäes talle alluv Pskov.

Köige tihedamini oli Novgorodiga seotud Kagu-Eesti, mille keskusteks olid Tartu ja Otepää. Novgorodi vürstid, nagu varem Kiievi vürstidki, püüdsid endile kindlustada andamit ka teistest Eesti piirkondadest, nimelt Virust, Vaigast, Järvast ja Harjust. Novgorodlased lugesid territooriumiks, kust neil on õigus nốuda andamit, Ida- ja Põhja-Eestit ,kuni mereni”. Nagu varem Kiievi vürstid, ei seganud ka Novgorodi vürstid ja bojaarid end maksualuse eestlaste maa siseasjadesse, jättes eesti ülikatele täiesti vabad käed elanikkonna maksustamise, kohtukorra, halduse ja usuasjade alal. See oli põhiliselt tingitud sellest, et vene feodaalidel puudusid siin maavaldused. Seetõttu oli maksualuse eestlaste maa kuulumine Novgorodi bojaaride vabariiki teistsuguse iseloomuga kui näiteks Pskovi, Laadoga, Vadja ja Karjala maade sinna kuulumine ${ }^{24}$.

Eestlaste ühendus Novgorodi riigiga leidis kajastust ka rahvusvahelistes suhetes. 1208. aastal, kui saksa röövvallutajad valmistusid eestlaste alistamisele, ei julgenud nad pikemata kallale tungida, vaid otsisid selleks mitmesuguseid ettekäändeid ja pidasid ugandlastega läbirääkimisi. Seejuures on iseloomulik, et sakslased valisid oma tõeliste röövvallutuslike eesmärkide varjamiseks seekord mitte kiriklik-religioosse ettekäände, nagu see „paganate” vastu oli tavaline, vaid materiaalse, mis näiliselt ei olnud vastuolus Novgorodi ja Pskovi bojaaride ja kaupmeeste huvidega. Sel teel loodeti vältida sõda Novgorodi ja Pskoviga, kelle kaitse alla osa Eesti maid kuulus.

Nii tõsteti algul üles küsimus talvise kaubatee julgeolekust ja hiljem ettekääne Novgorodile-Pskovile alluva Talava piirkonna feodaalidele ugandlaste poolt tehtud ,ülekohtust”. Hiljem, peapiiskop Alberti viitselegaadi poolt ordumeistrile antud ürikus 1248. aastast, märgitakse, nagu oleks vürst Jaroslav Tartu kirikule andnud Pskovi vürstiriigi, millest pool loovutatakse ordule ${ }^{25}$. Kuigi kinkimise lugu on saksa röövvallutajate poolt välja mõeldud pettus, on see siiski huvitav selles mōttes, et nad siin ise kinnitavad niihästi Tartu piiskopi maade kui ka ordu Lõuna- ja Kesk-Eestis ning Põhja-Lätis olevate valdusalade endist kuulumist Pskovi maade hulka.

Feodaalsuhete arenemise ja feodaalse killustumuse kujunemise tingimustes on arusaadavad ka need mõningad sõjalised kokkupõrked, mis tekkisid XI sajandi teisel poolel ja XII sajandil lahkhelidest Eesti ülikate ja KiieviNovgorodi vürstide vahel. Samalaadseī̄ kokkupõrkeid esines tollal ka üksikute vene vürstiriikide eneste vahel. Need väljaastumised likvideeriti vene vürstide poolt sõjakäikudega (näiteks aastail 1116, 1133, 1191-1192). Niisugused lühiajalised kokkupỗked, mida pealegi lahutavad osalt üle ühe inimpõlve kestnud rahuperioodid, ei suutnud nimetamisväärselt häirida eestlaste ja venelaste vahelist sõbralikku ja viljakat suhtlemist, millest eespool oli juttu.

A. N. Nassonov püüab oma uurimuses „,,Vene maa” ja Muistse Vene riigi territooriumi kujunemine" näidata, et riigi territooriumi kasvu otsustavaks pōhjuseks oli feodaalse ülikkonna sõjalise organisatsiooni, sunniaparaadi tegevus, vürstide ja sõjapealikute tegevus ${ }^{26}$. Oigusega on kriitika märkinud selle väite ekslikkust, mis ei jäta mingit osa rahvale

24 Vrd. A. H. Н а сонов, tsiteeritud teos, lk. 83.

25 Liv-, Esth- und Curländisches Urkundenbuch III, Reval, 1857, nr. 200a, veerg 37.

$26 \mathrm{Vt}$. tsiteeritud teos, lk. 217. 
ega majanduslikele sidemetele ${ }^{27}$. Osa eesti hõimude minek Muistse Vene riigi koosseisu ei saanud põhjustatud olla peamiselt vürstide ja väepealikute tegevusest või maa sõjalisest alistamisest, vaid see kasvas välja hoopis kindlamal alusel. Seda põhjustasid sajandite vältel järjest tihenenud majanduslikud ja kultuurilised sidemed ning vastastikused huvid, rahvahulkade sõbralik ja viljakas suhtlemine, eesti ja slaavi hõimude vahetu territoriaalne naabrus ja osaline segunemine etnilisel piirialal. Eestlaste mitmekesised majanduslikud, poliitilised ja kultuurilised sidemed vene rahvaga Muistse Vene riigi perioodil kiirendasid tunduvalt tootlike jõudude, feodaalse baasi ja vastava pealisehituse arenemist Eestis. Vene progressiivne mõju kajastus mitmekesiselt ka eesti keele sõnavara rikastumises ja vaimse kultuuri arenemises.

Eesti rahvas on säilitanud helged mälestused Muistse Vene riigi aegadest oma rahvaluules. Korduvalt kohtame rahvaluules Kiievi nimetust. Kagu-Eestis levinud muistendites jutustatakse isegi maa-alusest teest, mis mõnest kohalikust paigast viivat Kiievini. Selline muistend säilitab ilmselt pärimusi muistsest ajast, mil Kagu-Eesti kuulus Kiievi-Venemaa koosseisu. Lähedased jooned ühendavad eesti rahvakangelast Kalevipoega nn. Kiievi bõliinade vägilastega. Kalevipoja tihedas koostöös venelastega, juttudes silla ehitamisest üle Peipsi, vene abist linnade ehitamisel ning võitluses välisvaenlaste vastu - kõiges selles on eesti rahvas talletanud oma põlised ajaloolised kogemused oma ustavast sõbrast ja kaitsjast vene rahvast. Ei ole juhuslik seegi, et rahvapärimuste järgi asetsevat Kalevipoja kalm Kuremäe piirkonnas, kus XII-XIII sajandil kujunes eestivene segaasustus.

Eesti kodanlik-natsionalistlikud ajaloolased, kes igati võltsisid eesti rahva ajalugu, püüdsid surnuks vaikida eesti-vene ajaloolisi põliseid sõprussidemeid ja Muistse Vene riigi progressiivset tähtsust eesti rahva arengus. Tänapäeval jätkavad imperialismi huvide teenistuses seisvad kodanlikud ajaloolased välismaal Muistse Vene riigi ajaloo normanistlikku moonutamist ${ }^{28}$. Nagu nägime, räägivad aga ajaloo faktid hoopis teist keelt. Kodanliku historiograafia kahjulike vooltsvaadete ja nende igandite vastu võitlemiseks on Nốukogude Eesti ajaloolastel vaja tugevdada eesti rahva tõelise ajaloo uurimist IX-XIII sajandi osas.

Majanduslikud, poliitilised ja kultuurilised huvid olid selleks kindlaks, püsivaks aluseks, mis tagas Muistse Vene riigi perioodil eesti ja vene rahva vahel tekkinud sidemete edasise arenemise.

Need sidemed kindlustusid ja laienesid XIII sajandi algul Baltimaade rahvaste ja vene rahva ühises kangelaslikus võitluses feodaal-katoliikliku agressiooni vastu. Neil raskeil võitlusaastail otsisid ja said eestlased jälle korduvalt abi Venest. Selle abi eredateks näideteks on vene-eesti ühisvägede hiilgav võit saksa röövvallutajate üłe Otepääl 1217. aastal ja ühisretk taani röövvallutajate vastu Tallinna alla 1223. aastal ning Tartu kangelaslik kaitsmine vürst Vjatško juhtimisel. 1223. aastal paigutas vürst Jaroslav oma mehed Tartusse ja Otepääle, ,et valitseda Ugandis ja kogu Eestis”, nagu on märgitud „Liivimaa kroonikas" ${ }^{29}$. Novgorodist saadeti Tartusse vürst Vjatško, et abistada eestlasi võitluses saksa ristisõdijate vastu. Eestlased võtsid Vjatškot, nagu kroonikas kirjutatakse, „,rõõmuga vastu, et

27 Vt. „Bопросы истории”, 1953, nr. 8, lk. 167-168; M. N. Tihhomirovi ettekanne Moskvas 1954. a. aprillis, NSV Liidu Teaduste Akadeemia sessioonil Ukraina Venemaaga taasühinemise 300. aastapäeva tähistamiseks („Boпросы истории”, 1954, nr. 6, lk. 20).

28 Vt. Д. А. А в д у и н. Неонорманистские измышления буржуазных историков. „Вопросы историн”, 1953, nr. 12, lk. 114-120; J. S a s kols ki i, Kaasaegsete Eesti ajaloo võltsijate manipulatsioonid. „Eesti Kommunist”, 1953, nr. 8, 1k. 37-47.

29 Генрих Латвийский, Хроника Ливонии, М.-Л. 1938, стр. 425. 
muutuda tugevamaks teutoonlaste vastu, ja andsid talle maksu ümberkaudsetest maadest" ${ }^{30}$. Nendeks kroonikas mainitud maadeks olid Ugandi kõrval veel Vaiga, Viru, Järva ja Sakala, seega ligikaudu sama piirkond, kust oli juba varem Novgorodile andamit makstud.

On ilmne, et juba eelnevate sajandite jooksul välja kujunenud poliitiline ühendus oli soodustavaks teguriks ühises võitluses lääne röövvallutajate vastu.

Ainult Muistse Vene maade nõrgenemise tõttu, mis oli feodaalse killustumuse ja suurel määral tatari-mongoli khaanide vallutuste tagajärjeks, läks saksa-taani-rootsi feodaalidel korda Kirde-Venemaa küljest ära kiskuda Balti mere idaranniku maad. Vene vägede otsustav võit penirüütlite üle Jäälahingus 1242. aastal paiskas nad lôplikult tagąsi Vene piirilt ja kõigutas saksa feodaalide võimu kogu Ida-Baltikumis. Samal ajal takistas Venemaa ka tatari-mongoli vägede edasitungi loode suunas ja vältis sellega Baltimaade langemist nende rüüstamise ja ikke alla. On tähelepanuväärne, et eesti rahvas on kõrgelt hinnanud seda kaitset, mida venelased andsid Euroopa rahvastele idapoolsete rändrahvaste kallaletungide vastu. See avaldub eesti rahvaluules ja ajaloolistes muistendites ${ }^{31}$.

Saksa feodaalid kehtestasid Eestis väga ränga feodaalse ja rahvusliku rõhumise ning omavoli. Nad püüdsid iga hinna eest purustada eesti rahva sōbralikke sidemeid vene rahvaga. Eesti rahva mälestusest ei suutnud aga mingi jõud kustutada teadmist muistsest ühendusest Venemaaga, vene rahva abist ja toetusest. Poliitilisele piirile vaatamata jätkus eestlaste sõbralik läbikäimine venelastega.- Lakkamatus võitluses võõramaiste orjastajate rōhumise vastu pöördusid eestlaste pilgud alatasa Venemaa ja vene rahva poole, kellega ühinemine oli neile ainsaks pääsemislootuseks. Jüriöö ülestõusu ajal 1343. aastal läkitasid harjulased Pskovi saadikud, kes kutsusid venelasi võtma maad oma võimu alla. Kui ordu 1501. aastal alustas sõda Vene riigi vastu, hakkasid talupojad suurtes salkades üle minema venelaste poole, ja see oli üheks põhjuseks, mis sundis agressoreid ruttama rahu paluma. Liivi sõja algul alistusid eestlased kõikjal meelsasti Vene riigile ning aitasid mitmel viisil kaasa sakslaste lüüasaamisele. Eestlased näitasid korduvalt tegudega, et nad on valmis koos venelastega võitlema saksa ja rootsi feodaalide ning poola šlahta vastu. Alates XIII sajandist kuni XVIII sajandi alguseni, millal Eesti Põhjasõjas ühendati Vene riigiga, oli Venemaa selleks keskuseks, kust rõhutud eesti rahvahulgad said abi ja toetust võitluses võõramaiste orjastajate vastu.

Baltimaade ühendus Muistse Vene riigiga ei kustunud ka vene rahva teadvusest. Venelased vaatasid sakslastele siin kui sissetungijatele, kes on orjastanud kohalikud põlisrahvad ja nad lahti kiskunud Venemaa küljest. Kuid alles pärast seda, kui vene rahvas purustas tatari-mongoli ikke, sai võitu feodaalsest killustatusest ning rajas võimsa tsentraliseeritud riigi pealinnaga Moskva, saadi alustada otsustavat võitlust ka saksa feodaalvõimude vastu Liivimaal. XV sajandi teisel poolel ja XVI sajandi algul sunniti viimaseid vaherahulepingutes tunnustama Vene riigi muistset õigust andami saamiseks Kagu-Eesti alalt. Tõusva Vene riigi võitlus väljapääsu eest Balti merele kasvas välja tema majanduslikest, poliitilistest, sõjalistest ja kultuurilistest vajadustest ning vastas ka Baltimaade rahvaste arenemise põhilistele huvidele.

Vene diplomaatias ei etendanud mitte väikest osa Vene riigi õigustatud nõudmiste pōhjendamine ajalooliste argumentidega Liivimaast kui „pärusmaast”. Ivan Groznõi kirjutas: „Liivimaa on igivanast ajast peale meie

so Samas, Ik. 426-427.

s1 Vt. Eesti kirjanduse ajalugu I, Tallinn, 1953, 1k. 47. 
pärusmaa: suurvürst Jaroslavist, ... kes vallutas Tšuudimaa ja ehitas sinna linna, mida tema nime järgi nimetatakse Jurjeviks, kuid saksa keeles Derptiks, seejärel aga suurest valitsejast Aleksander Nevskist peale; Liivimaa kohustus juba ammu maksma andamit..." ${ }^{32}$ Taani kuninga saadikutele, kui nad, toetudes taani röövvallutajate ajutisele võimule Eestimaal XIII ja XIV sajandil, Tallinna nimetasid kuningale kuuluvaks, laskis Ivan IV 1559. aastal vastata, et „... on absurdsus, kui kuningas nimetab Tallinna ja Virumaad oma maaks: need on iidsest ajast tsaari maksualused (maad) ja nüüd tahab valitseja neid oma nimel pidada ja kindlasti ka tulevikus ning kuningas ärgu tulgu Tallinna ja Virumaale, kui ta ei soovi valitsejaga riidu (minna)" ${ }^{33}$. Peeter I nimetas Tartut ,esiisade linnaks" 34 .

Ukraina ja Valgevene vabastamine leedu ja poola magnaatide ja šlahta ikke alt oli balti küsimuse lahendamisega tihedasti seotud. XVI sajandi teisel poolel, kui poola ja leedu feodaalidel oli võimalik kasutada Ukraina ja Valgevene alade majanduslikke ressursse, oli see üheks teguriks, miks paljude välis- ja sisevaenlaste vastu võitlev Vene riik ei suutnud säilitada vabastatud Liivimaad.

Ukraina rahva vabadusvõitlusel ja taasühinemisel vene rahvaga ühtses Vene riigis oli väga suur tähtsus ka eesti ja läti rahva vabastamisele Rootsi koloniaalikke alt. Ukraina taasühinemine tugeva tsentraliseeritud Vene riigiga aitas kaasa mitte ainult Ukraina, vaid ka Venemaa tootlike jõudude kasvule. „Venemaa ja Ukraina majanduslike ressursside ühendamine mitmekordistas vene ja ukraina rahva jõudu nende ühises võitluses võõramaiste röövvallutajate vastu" ${ }^{35}$. See oli üheks oluliseks eelduseks ka nn. balti küsimuse lahendamisel. Venemaa viis nüüd võidukalt lõpule Ida-Baltikumi vabastamise rootsi anastajate võimu alt. 250 aastat tagasi, 1704. aastal, vabastati Tartu ja Narva, need juba Muistse Vene riigi koosseisu kuulunud piirkonnad. 1709. aastal purustas Vene armee, mille koosseisu kuulusid Ukraina väeosad, Poltaava all rootsi röövvallutajad. See võimaldas järgmisel aastal vabastada Riia ja Tallinna ning rootsi väed lõplikult välja kihutada Eesti ja Läti aladelt ning need taasühendada Vene riigiga.

Hoolimata sellest, et Venemaa eesotsas seisid tookord tsaar ja mõisnikud, oli Eesti ühendamisel Venemaaga määratu suur progressiivne tähtsus eesti rahvale. Eesti taasühendamine Venemaaga oli vene ja eesti rahva kogu eelnenud ajaloo, majanduslike, poliitiliste ja kultuuriliste sidemete seaduspärase arenemise tulemus, mis oli täiesti kooskõlas Eesti maa ja rahva arenemise huvidega. Taasühendamine Vene riigiga kindlustas Eestile püsiva rahuperioodi, tootlike jõudude edasise kasvu, majanduse ja kultuuri arenemise. Eesti taasühendamine Venemaaga tähendas eesti rahva vabastamist Rootsi aadliriigi sõjalis-koloniaalsest ikkest, vältis Eesti langemist šlahta-Poola alla ja tema vallutamist preisi junkrute või ingliseprantsuse kolonisaatorite poolt.

Alates XVIII sajandi algusest ühendati eesti rahva saatus jäädavalt ja lahutamatult vene rahva saatusega, ukraina ja teiste Venemaa rahvaste saatusega. Vene, ukraina ja teiste meie maa rahvaste ühises võitluses tsarismi; mõisnike, kapitalistide ja võõramaiste röövvallutajate vastu saa-

32 Послания Ивана Грозного. Под ред. В. П. Адриановой-Перетц. М.-Л., 1951, стр. 202.

33 Полное собрание русских летописей, т. 13, ч. 2, стр. 318.

34 Письма и бумаги императора Петра Великого. Том третий, СПб. 1893, стр. 168: \&... сей праотечественный город...»

35 Teesid Ukraina Venemaaga taasühinemise 300 . aastapäeva kohta (1654-1954); Tallinn, 1954, Ik. 10. 
vutas ka eesti rahvas lōpuks oma sotsiaalse ja rahvusliku vabastamise. Kommunistlik partei viis kõik meie maa rahvad proletariaadi diktatuuri kehtestamisele ning nõukogude kord avas tee nende majanduslikuks ja kultuuriliseks õitsenguks.

Vennalikus liidus on NSV Liidu rahvad kommunistliku partei juhtimisel üles ehitanud sotsialismi ja sammuvad tänapäeval kindlalt edasi kommunismi triumfile. Meie maa rahvad, sealhulgas ka eesti rahvas, ei unusta kunagi oma suuri ajaloolisi kogemusi, mis on õpetanud neid nägema oma õnne ja vabaduse panti lahutamatus ühtsuses vene rahvaga ja teiste meie kodumaa rahvastega.

NSV Liidu rahvaste vääramatu sõprus on meie suure kodumaa jõu ja võimsuse allikas.

\author{
Eesti NSV Teaduste Akadeemia \\ Ajaloo Instituut
}

\title{
ЭСТОНСКИЕ ЗЕМЛИ В СОСТАВЕ ДРЕВНЕРУССКОГО ГОСУДАРСТВА *
}

\author{
A. K. BACCAP, \\ кандндат исторических наук
}

Резюме

Между эстонскими и восточнославянскими племенами существовали извечные экономические и культурные связи. Об этом свидетельствуют прежде всего археологические и языковые данные. В I тысячелетии н. э. поселения кривичей достигали непосредственно юго-восточной Эстонии (распространение длинных курганов); местами здесь существовали и смешанные эстонско-славянские поселения. Славянское влияние отражаеся в тот период как в материальной культуре, так и в словарном фонде языка эстонцев.

Тесная связь эстонцев с древнерусским государством явилась непосредственным продолжением и дальнейшим развитием того экономического и культурного общения, которое до этого уже в течение долгого времени существовало между эстонскими и славянскими племенами. Подчинение эстонцев киевским князьям явилось закономерным следствием всего предшествующего хода развития и возникновения классового общества. Оно обусловлено также общими политическими интересами в борьбе против разбойничьих набегов варягов.

В IX-XII веках в Әстонии наблюдался значительный рост производительных сил, вошла в употребление соха с железными наконечниками, началось отделение ремесла от земледелия, возникли центры городского типа - Колывань (Таллин), Юрьев (Тарту) и др. Тесная связь с русскими, достигшими к тому времени более высокой ступени общественноэкономического и культурного развития, в значительной степени способствовала росту производительных сил в Эстонии, ускорила формирование феодального базиса и надстройки.

Особенно сильное славянское влияние попрежнему наблюдается в юго-восточной Эстонии. Оно отражается в распространении могильных курганов славянского типа, керамики, изготовленной на гончарном круге,

* Доклад на сессии Академии наук Эстонской ССР в ознаменование 300-летия воссоединения Украины с Россией, 13 мая 1954 года. 
украшений, изготовленных в русских городах, и т. д. В XI-XII веках происходит территориальное сближение эстонцев, населявших северовосточную Әстонию, со славянами. Возникают также эстонско-водьскославянские смешанные поселения к северу от Чудского озера. Многочисленные находки монет и кладов, сосредоточенные на территории Эстонии в районе крупных центров, гаваней и важнейших путей сообщения, свидетельствуют о том, что торговля с Русью в IX-XII веках имела очень большое значение в хозяйственной жизни Әстонии.

Әстонская феодализирующаяся знать была заинтересована в подчинении русским князьям, ибо это обеспечивало ей эксплуатацию народных масс, открывало перед ней возможности обогащения за счет участия в военных походах и приобретения феодальных владений. Летописи неоднократно упоминают об участии эстонцев в военных походах новгородских и киевских князей. Из числа эстонской знати вербовались также вонны для охраны южных государственных границ против степных кочевых орд. Отдельные выходцы из верхушки эстонской знати, состоявшие на службе у киевских князей, добились довольно выдающегося положения (Микула Чудин и его брат Тукы во второй половине XI века).

Помощь русского народа дала возможность эстонцам отбить все нападения скандинавов в IX-XII веках.

Наиболее прочно входила в состав древнерусского государства юговосточная Эстония, центрами которой являлись Тарту и Отепяа. Киевские князья, а в XII и в начале XIII столетия и новгородские князья распространили данничество на всю восточную и северную Әстонию.

Русские князья не вмешивались во внутренние дела подчиненной им земли эстонцев, обычно не создавали здесь своих крупных землевладений, не осуществляли военной оккупации и насильственного обращения в христианство, ограничиваясь главным образом сбором дани и обеспечением безопасности торговых путей. Некоторые разногласия, которые возникали в условиях феодальной раздробленности у эстонской имущей верхушки с русскими князьями, ликвидировались военными походами. Эти непродолжительные и редкие столкновения не могли в скольконибудь значительной степени нарушить дружественное, покоящееся на общности интересов, благотворное общение между русскими и эстонцами.

Әстонский фольклор сохранил предания, которые свидетельствуют о дружественном отношении эстонцев к древнерусскому государству.

Возникшее в период древнерусского государства политическое объединение явилось плодотворным фактором в совместной борьбе прибалтийских и русского народов против западной феодально-католической агрессии в XIII веке.

Немецкие захватчики, установив в Ливонии жесточайший крепостнический и национальный гнет, стремились любой ценой порвать дружеские связи между эстонским и русским народами. В непрерывной борьбе против гнета иноземных поработителей взоры эстонцев постоянно обращались к России и русскому народу, объединение с которым в едином русском государстве являлось для них единственной надеждой на спасение. Особенно ярко это проявлялось на решающих этапах борьбы - в 1343 г. во время восстания в Юрьеву ночь и в годы Ливонской и Северной войны.

Вхождение прибалтийских земель в состав древнерусского государства сохранилось и в памяти русского народа. Русская дипломатия использовала исторический аргумент о Ливонии как «отчине» для обоснования справедливых требований централизованного русского государства в борьбе за выход к Балтийскому морю. 
Воссоединение Украины с Россией создало, наконец, благоприятные условия для освобождения эстонского и латышского народов из-под колониального гнета Швеции. Объединение экономических ресурсов России и Украины приумножило силы русского и украинского народов в их совместной борьбе против иноземных захватчиков. В Северной войне Россия победоносно завершила освобождение Восточной Прибалтики из-под власти шведских агрессоров. Территории Әстонии и Латвии вошли в состав Российского государства. Это имело огромңое прогрессивное значение для дальнейшего развития эстонского и латышского народов.

В совместной борьбе русского, украинского и других народов нашей страны против царизма, помещиков, капиталистов и чужеземных захватчиков эстонский народ также добился наконец своего социального и национального освобождения. Коммунистическая партия привела все народы нашей страны к установлению диктатуры пролетарната; под руководством партии народы СССР в братском союзе уверенно идут к коммунизму.

Институт истории

Академии наук Эстонской ССР 